\title{
A Comparative Analysis of Effective Free Trade Zone Policies in Ghana: A Model from Shanghai Free Trade Zone
}

\author{
Dechun Huang ${ }^{1}$, Ebenezer Nickson Neequaye ${ }^{1 *}$, Jonathan Banahene ${ }^{2}$, Vu Thi Van ${ }^{1}$, Stella Fynn ${ }^{1}$ \\ ${ }^{1}$ Institute of Industrial Economics, Hohai Business School, Hohai University, Nanjing, China \\ ${ }^{2}$ Management Department, Jiangsu University, Zhenjiang, China \\ Email:^huangdechun@hhu.edu.cn,npapacy@yahoo.com,vuvan1690@gmail.com, fynnstella@yahoo.com, ^nabossvic@yahoo.com
}

How to cite this paper: Huang, D.C., Neequaye, E.N., Banahene, J., Van, V.T. and Fynn, S. (2018) A Comparative Analysis of Effective Free Trade Zone Policies in Ghana: A Model from Shanghai Free Trade Zone. Open Journal of Business and Management, 6, 900-922.

https://doi.org/10.4236/ojbm.2018.64066

Received: May 25, 2018

Accepted: October 15, 2018

Published: October 18, 2018

Copyright $\odot 2018$ by authors and Scientific Research Publishing Inc. This work is licensed under the Creative Commons Attribution International License (CC BY 4.0).

http://creativecommons.org/licenses/by/4.0/

\begin{abstract}
The importance of export promotion contribution to the growth of a country's economy cannot be underrated. It is well-established that, encouraging volumes of exports and/or value of exports results in the increase in the export of a country leading to an increase in earnings of foreign exchange and further results in economic boost of a country. A comparative analysis of effective Free Trade Zone Policies in Ghana using China (Shanghai) Pilot Free Trade Zone ("SHFTZ") as a model has been done. Desktop research was used to analyze the data. It was found that there has been year on year increase in the number of companies registering with the Ghana free zones. On the average, there have been about 15\% contribution to the gross export of Ghana. The China (Shanghai) Pilot Free Trade Zone ("SHFTZ") contributed 5.68\%, $13.2 \%, 15.2 \%$ and $22.9 \%$ from the first quarter after the inception of the FTZ, at the end of 2014, 2015 and 2016 respectively to the GDP of Shanghai.
\end{abstract}

\section{Keywords}

Ghana Free Zones, Export Processing Zone, China (Shanghai) Pilot Free Trade Zone (“SHFTZ”), SHFTZ GDP

\section{Introduction}

One strategy to achieve a good economic performance is to increase export. Free Zones has been identified and been used vigorously as an export support strategy [1]. The free trade zone historically, dates back to the ancient Phoenicians era, when safe passage was the principal guarantee offered foreign traders coming to Tyre and Carthage [2], Free Trade Zone in the beginning were tools for the ag- 
gressive commercial power [3]. The first concept of international free trade zone was created by the Phoenicians [4]. This was followed by the Greek City-States and the Romans, the Romans established it into launching pads that were used as a tool for economic and political supremacy. For centuries, secure trade routes like Singapore, Gibraltar and Hamburg have been operating citywide free zones and entrepots that have free storage and exchange guarantee [5]. As early as 1704 and 1819, Gibraltar and Singapore respectively had well established free trade zones [3]. In 1960s, the "United Nations' Economic and Social Council" adopted a resolution at the $1506^{\text {th }}$ plenary meeting on August 41,967 , suggesting that improving customs, ports and free zones infrastructure in developing countries is one of the primary ways of encouraging export expansion [5] [6]. In Shannon, Ireland in 1959 the first modern free zones of industrial scale were established [4].

United Nations Development Program defines Free Zones as the various types of geographically delimitated area that exist within a country, functioning with a distinct administrative, fiscal and regulatory systems, different from the remaining part of the country [7]. Economic experiments are carried out in these zones with infrastructure, regulatory, and fiscal policies, which differ from policies implemented in the remaining domestic economy, with the sole objective of employment creation boost in export and attraction of foreign direct investment [8]. Zones with these characteristics are given diverse names by different countries. These names are; Export Free Zones, Maquiladora, Industrial Free Zone, Duty Free Export Processing Zone, Export Processing Zone, Free Export Zone, Free Zone, Investment Promotion Zone, Foreign Trade Zone, Development Zones, Economic and Technological Development Zones (ETDZs), Hi-tech Development Zones (HIDZs) and Special Economic Zones (SEZs) [9] [10]. The international labour organization estimates about $3500 \mathrm{FZs}$ exist currently in the world in about 130 countries and territories. The number of countries using FZs increased to 130 in 2006 from 116 in 2002 and 25 in 1975 [11].

Policy-makers across the world especially developing economies are carrying out various forms of Free Zones (FZs) programs with the intension to catalyze economic growth. According to literature, the main implementation objective(s) of free zones is to serve at least one of the following four policy objectives; 1 ) foreign direct investment attraction to the country, export promotion and ultimately industrialization; 2) to serve as a "pressure valve" for large scale unemployment alleviation 3) serve as a pillar for a broader economic reform strategy and 4) serve as laboratories for new policies and approaches experimentation [3] [4] [12] [13] [14]. Free zones can be used as effective industrialization promotion mechanism and if executed correctly in the right context has the tendency to push the entire country on faster economic developmental trajectory [15] [16] [17] [18].

The Environment Kuznets Curve (EKC) theory is regarded as the most well-known theory regarding problems of environmental pollution brought by 
economic development. This theory has created several controversies, having many studies proved or disproved it since it was proposed. Jalil et al. and Coondoo et al. for example, studied the empirical relationship between economic growth and different environmental pollution indexes. They affirmed the existence of EKC theory [19] [20]. Relying on the panel data model, Stern, Aslanidis et al. and Perman et al. found on the contrary from their empirical studies, an inverted U-shape relationship did not exist between economic growth and environmental pollution as implied by the EKC theory [21] [22] [23]. In the opinion of some environmentalists "free trade can destroy the environment". Thus, a section of the large and powerful environmentalist lobbyist has joined the growing alliance of interests seeking to scuttle what is left of international free trade [24]. Shah and Rivera (2008) on the other hand revealed that in the case of Trinidad and Tobago's EPZs the situation is different and that facilities operating in the zones have a higher probability of better cooperate environmental performance when compared with those outside the zone [25].

The needed legislative instrument to regulate these zones requires adjustment of existing laws or enactment of new ones. In view of this the Standing Committee of the National People's Congress sanctioned the State Council to Provisionally adjust relevant portions of the "Law of the People's Republic of China on Wholly Foreign Owned Enterprises", "Law of the People's Republic of China on Sino-Foreign Equity Joint Venture Companies", and "Law of the People's Republic of China on Sino-Foreign Cooperative Joint Venture Companies" that deals with administrative examination and approval requirements and such adjustments will be put to use three years from $1^{\text {st }}$ October 2013 [26]. In the case if Ghana, the Free Zones Act 1995 (Act 504), "an act to enable the establishment of free zones in Ghana for the promotion of economic development; to provide for the regulation of activities in free zones and for related purposes", was enacted by parliament to among other things facilitate the establishment of free zones in Ghana and also to provide for the regulation of activities in the free zones and its related purposes. The Act received Presidential assent in August 1995. Implementation of the Program began in September 1996 with the establishment of the Ghana Free Zones Board Secretariat [27]. The law made provision for the following: Establishment of free zones board and related provisions, Establishment of free zones; Developers of free zones, Free zone enterprises, Licensing, Import and export, Incentives, Administration and miscellaneous provisions [27].

Several countries have had success with their SEZ, contributing immensely to their economic development whereas others have had utterly unsuccessful implementation of their SEZ. For instance, the government of the Philippines made substantial infrastructural investment for their zone in Bataan. This involved the upgrade of the port, erecting an elegant office building and the construction of a new energy supply dam. However, the much attraction needed for business to be established in the zone failed, rendering the project a very expensive failure to the Philippine government [28]. The Chinese government in 2013 created the 
China (Shanghai) Pilot Free Trade Zone with the intension of putting to test relaxed trading practices [29], in addition to the many types of free zones created already. Ghana in 1995 created the Ghana free Zones with the aim of promoting economic development, beginning with Tema Export Processing Zone [27]. This paper will do a comparative analysis of effective Free Trade Zone Policies in Ghana using China (Shanghai) Pilot Free Trade Zone ("SHFTZ”) as a model.

\section{Evolution of Free Trade Zone}

\subsection{Evolution of the China (Shanghai) Pilot Free Trade Zone Policy}

From the period of 1949 to some years before 1979, when Mao Zedong was the Leader and the rise of Communism, China Exhibited little interest in international business transactions. During This period, China's import-export trade was less than 10 Percent of her national income, because China neither allowed nor received foreign investments on her territory [30]. China Became more open to foreign investments only after the fall of the Gang of Four in 1976 [31]. The Chinese government actually embraced the free trade zones concept in the early 1980s when Deng Xiaoping promoted an economic “open-door policy" [10]. After the Third Plenum of the $11^{\text {th }}$ Congress in 1978, the Communist Party of China (CCP) and the Chinese government introduced some major political changes: they established four special economic zones in 1979, setting forth the as a national policy the development of the coastal region in the Sixth Five-Year Plan (1981-1985) [32].

In 1984, 14 coastal cities were opened; three deltas-the Lower Yangtze delta, the Xiamen-Zhangzhou-Quanzhou Triangle and the Pearl River Delt-were declared as Coastal Economic Development Zones, and Hainan was established as a special economic province [32]. China used Special Economic Zones to pioneer new economic policies, provide modern infrastructure and attract investment for export-oriented industries [33]. In 2008, a World Trade Organization policy review reported that as of 2006, china had 660 SEZs in addition to other development zones that were sanctioned by the central government and 1346 additional development zones sanctioned by local government [34]. The Peoples' Republic of China (PRC) is the largest exporter in the world and the second largest importer. The only developing country on the list of the world's top ten exporter's aside Russia is China [29]. In December 2005, the PRC established its first FTZ located in a port-the Yangshan Free Trade Port Area [26]. This FTZ had all of the offices associated with a port including customs, taxes, maritime affairs, and border inspection. In July 2009, the State Council approved Pudong Airport Free Trade Zone, the fourth component SEZ. Most of the investment related with this FTZ comes from Pudong International Airport [29]. The service that it offers are the same as that of the SEZs in the SHFTZs and the success of the Pudong Airport Free Trade Zone is attributed to its superior air and land transport systems. Pudong Free Trade Zone went into strategic development alliance with the other three SEZs called the ("Three Ports, Three 
Areas") four months after its establishment [29].

Despite its enormous trade volumes, the national government is encouraged to test new methods to promote international trade and foreign investments due to the slowing domestic economy. The NPC on August 30, 2013, promulgated the "Decision of the Standing Committee of the National People's Congress sanctioning the State Council to Provisionally Adjust the Applicable Administrative Approval Items Set in Laws in China (Shanghai) Pilot Free Trade Zone". The four aforementioned SEZs were stated in this legislation to be merged into one single FTZ and authority was given to the State Council to create administrative guidelines to set up and regulate the SHFTZ for three years. Pursuant to this document, the SHFTZ was established on October 1, 2013 [29]. The most advanced Shanghai Pilot Free Trade Zone (SPFTZ) in Shanghai was reinvigorated by the government of China in September 2013 and is seen as another key step by China towards its ambition of returning Shanghai back into a principal global trading and financial hub [35]. One purpose of setting up the free trade zone is to use it as a policy testing ground and spread it consecutively to other parts of the country when those policies and practices have fully-fledged [35].

\subsection{Evolution of the Ghana Free Zones Policy}

Export promotion as a tool for economic growth is highly emphasized. It is acknowledged in theory that promoting volume and/or value of exports brings an increase in exports, increases foreign exchange and further improves a country's economy. Success in manufactured exports has been measured to be synonymous with rapid economic development. In the last thirty years' success in manufactured exports has been nearly synonymous with rapid economic development [36]. Export promotion in Ghana is seen as an important policy instrument for the country in achieving sustainable economic growth. In order to promote competiveness in Ghana exports, several policy instruments have been adopted. These include the Economic Recovery Program (ERP) initiated in 1983. The Free Zones policy instruments have become a very popular instrument after its introduction. Free zones have become important part of policy instruments in developing economies in their quest to attract foreign investment, promote non-traditional exports and to increase exports in total [37].

After 15 years of economic reforms prior to the inception of the Free Zones program in Ghana, Ghana's business environment was said to be amongst the best in Africa for private sector development. This was after a benchmark study was commissioned by the Government of Ghana for the Gateway project to compare investment climate to those of Mauritius and Dubai (considered best practices); and Togo and Kenya (potential competitors). The study confirmed that Ghana compares favorably to Togo and Kenya and had advantages that make it attractive to Mauritius and Dubai. However, foreign investors in Asia, Europe and other parts of the world were largely not aware of the Ghana's business potential both as a platform for production for the world markets and also 
as a gateway to the West African sub-region. The Free zones under the Gateway project was established to pull in a large number of investors who were export-oriented in order to facilitate export-led growth and trade in general. Ghana in a bid to kick-start the growth of the economy, adopted the free zones concepts over a decade ago. This was meant to attract investment and capital and to encourage competitive enterprises focus mainly to produce for export [37].

\section{Objectives for Setting up the Free Zones}

\subsection{Objectives of the China (Shanghai) Pilot Free Trade Zone}

The State Council issued the "China (Shanghai) Pilot Free Trade Zone Overall Plan" ("SHFTZ Plan") within three weeks after the NPC promulgated the document that gave authority to the State Council over the SHFTZ. The principal objectives of China (Shanghai) Pilot Free Trade Zone (SHFTZ) are:

1) To accelerate governmental change in accordance with a changing economic environment [29].

2) To research new methods of administrative regulation [29].

3) To promote trade and investment [29].

4) To serve as an experiment for national regulatory reform [29].

The SHFTZ Plan provides guidelines for the initial three years of the SHFTZ, it focuses on reforms concerning foreign investment, trade, financial services, merchandise classification, and currency exchange [29]. With the above main objectives, six areas of focus for the free trade zone were emphasized to bring forth the multi-layered mission of the SPFTZ. These are: financial services; shipping and logistics; commercial trade; professional services such as law and engineering; culture and entertainment; and social services including education and healthcare [35].

\subsection{Objectives of the Ghana Free Zones}

The Ghana free Zones was established to achieve the below objectives:

- Attraction of Foreign Direct Investments [38];

- Creation of employment opportunities [38];

- Increasing foreign exchange earnings [38];

- Provision of business opportunities for foreign and local investors to undertake joint-venture [38];

- Enhancement of technical and managerial skills/expertise of Ghanaians; Promotion of the transfer of Technology and Diversification of Exports [38].

\section{Governance of the Free zones}

\subsection{Organizational Structure of SHFTZ-Economic Zones and the Decentralized Governance Model}

China's path of development has closely resembled those of Taiwan, Singapore and South Korea in the sense that economic development has been accompanied and enhanced by the central authority being delegated, and promoting sufficient 
autonomy for domestic social groups and markets [39]. There has been a recognizable increase in the power of the local government to regulate the areas under their jurisdiction as a result of decentralization of economic power to lower administrative levels. While carrying on this process, market mechanisms have been transplanted into the economic arena [35]. The SHFTZ is made up of a complex structure of decentralized governance model of governmental organizations (Figure 1) that are categorized into two administrations for industry and commerce (“AICs") and a variety of local offices [29].

\subsection{Governance of the Ghana Free Zone Authority}

The organizational structure of the Ghana Free Zones Authority is depicted in Figure 2. It has nine members of which the President appoints in consultation with the Council of State. The Minister of Trade and Industry chairs the board. The board's main role is to facilitate, regulate and monitor activities in the free zones [41].

\section{Incentives Provided by the Free Zones}

\subsection{Incentives of China (Shanghai) Pilot Free Trade Zone}

\subsubsection{The Negative List}

China has a list code named "Positive List" that identifies business activities that

\section{China (Shanghai) Pilot Free Trade Zone Administration Shanghai FTZ Authority}

Departments Under the Administration

Administrative Office

Human Resources Department

Economic Development Department

Fiscal and Financial Services Department

Planning, Construction and Environmental Department

Supervision and Law Enforcement Department

Yangshan Free Trade Port Area Office

Waigaoqiao Free Trade Zone Office

Pudong Airport Free Trade Zone Office
Organizations Under the Administration

Shanghai FTZ Bonded Area Law Enforcement Brigade

Shanghai TFZ Bonded Area Information Center

Shanghai FTZ Bonded Area Urban Construction and Management Center

Shanghai FTZ Bonded Area Investment Service Center

Figure 1. Organizational structure of SHFTZ (Adopted from: Shanghai free trade zone website) [40]. 


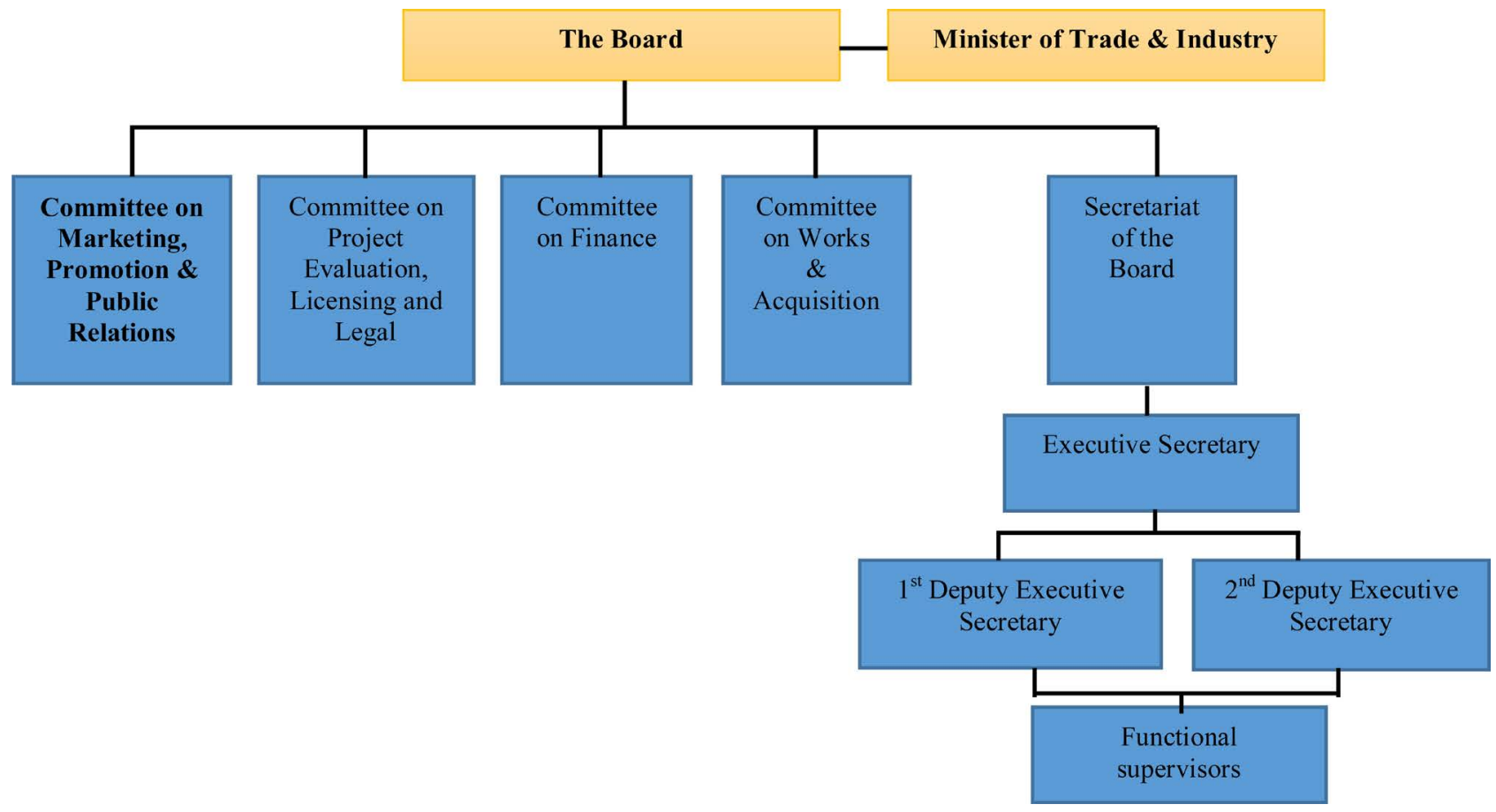

Figure 2. Ghana free zone authority organizational structure (Deduced from: GFZA Profile, 2018) [41].

can be done by foreign investors with the Chinese territory. Any business activity aside what is found on that list is forbidden to be run by a foreign investor. This is still employed outside the SHFTZ SFTZ2. With SHFTZ, foreign investors are able to invest freely in sectors not on the "Negative List" without any constraints or any joint venture requirements. Foreign enterprises register their projects, without the need to apply for approval. Thus, investments by foreign entities domestic entities go through the same procedures [42].

\subsubsection{Faster, Simpler Business Registration}

The business registration approval duration has been reduced to less than a week, while import and export license takes two weeks. The steps needed for the business registration (Figure 3) has also been made easy. The authorities are providing a One-stop filing and registration procedure instead of an approval process. The company is able to complete other necessary procedures on its own [43]. Minimum capital requirements for companies in particular industries, for instance financial companies that provide loan services have been relaxed. In the SHFTZ annual inspection system has been substituted with annual reporting [42]. Furthermore, having a virtual office in the SHFTZ is possible but this is not permitted in all parts of China [44].

\subsubsection{Trade}

The SHFTZ opens up the business front line (the boundary between the Shanghai SHFTZ and overseas) and effective control in the second business line (i.e. the boundary between the SHFTZ and the rest of mainland China), and then free flow within the SHFTZ itself: The sales of the products into the non-FTZ 


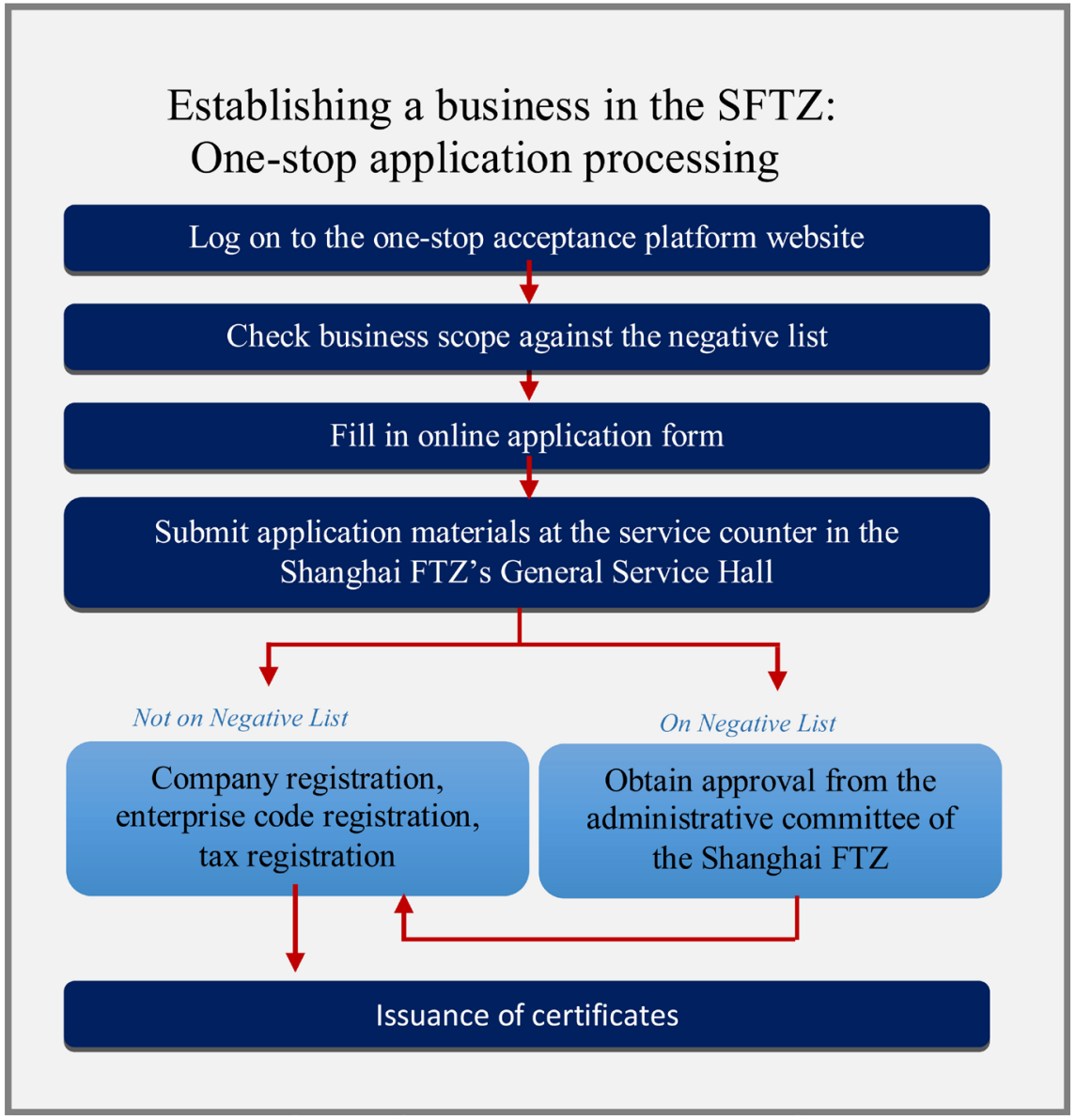

Figure 3. Processes for establishing a business in SHFTZ (Adopted from: Grmanova. CzehTrade) [42].

from the SHFTZ is regarded as domestic import implying that applicable processes have to follow, Frontier Opening: This implies products will be given entry into the zone while declarations can be made online. It is worth mentioning that, in the past, getting customs declared with entry and exit filing checklist could delay up to 14 days, Second-tier Safe and Efficient Control: This includes optimizing and improving the e-information network and accounting book management of the customs administration process between SHFTZ and the Mainland China, Shipping manifest from the supplier can be used for customs clearance even before the arrival of the product into SHFTZ, Companies within the SHFTZ can make Paperless declarations online, Goods do not have to be conveyed out of the SHFTZ within six months, Shipping bill is the only thing that can be used to deliver overseas shipments instead of a formal customs declaration, Yangshan Port-Goods staying in the zone are exempted from import tariff, Custom clearance speeding up: Import duties and VAT on finished (modified in the zone) products either of the rates applicable on the finished products or the components (pay taxes only for the imported part which have been used) and Avoid foreign exchange risk: Imports and Exports to and from within Mainland China are considered non-domestic hence the customer or supplier is 
made to pay as foreign investor in a foreign currency after handling clearance documents [36] [42] [45].

Companies within SHFTZ can enjoy free transfer of funds between and in-between FTAs and accounts outside Mainland China. Transactions with the accounts that is within Mainland China are handled as cross-border. Moreover, companies operating in the SFTZ are allowed to use FTAs to borrow offshore loans (foreign debt) up to a maximum of twice the company's capital (paid-in capital + capital reserves) from outside Mainland China [46]. Companies operating within SHFTZ can get overseas RMB loans (exclusively for activities in the zone). RMB will be freely convertible under capital account. RMB settlement for cross-border e-commerce via authorized institutions registered in Shanghai or branches registered in the SHFTZ. Cross-border RMB cash pooling and netting (it is not possible in Financial Sector) and interest rate liberalization [42]. Figure 4 depicts these above financial advantages.

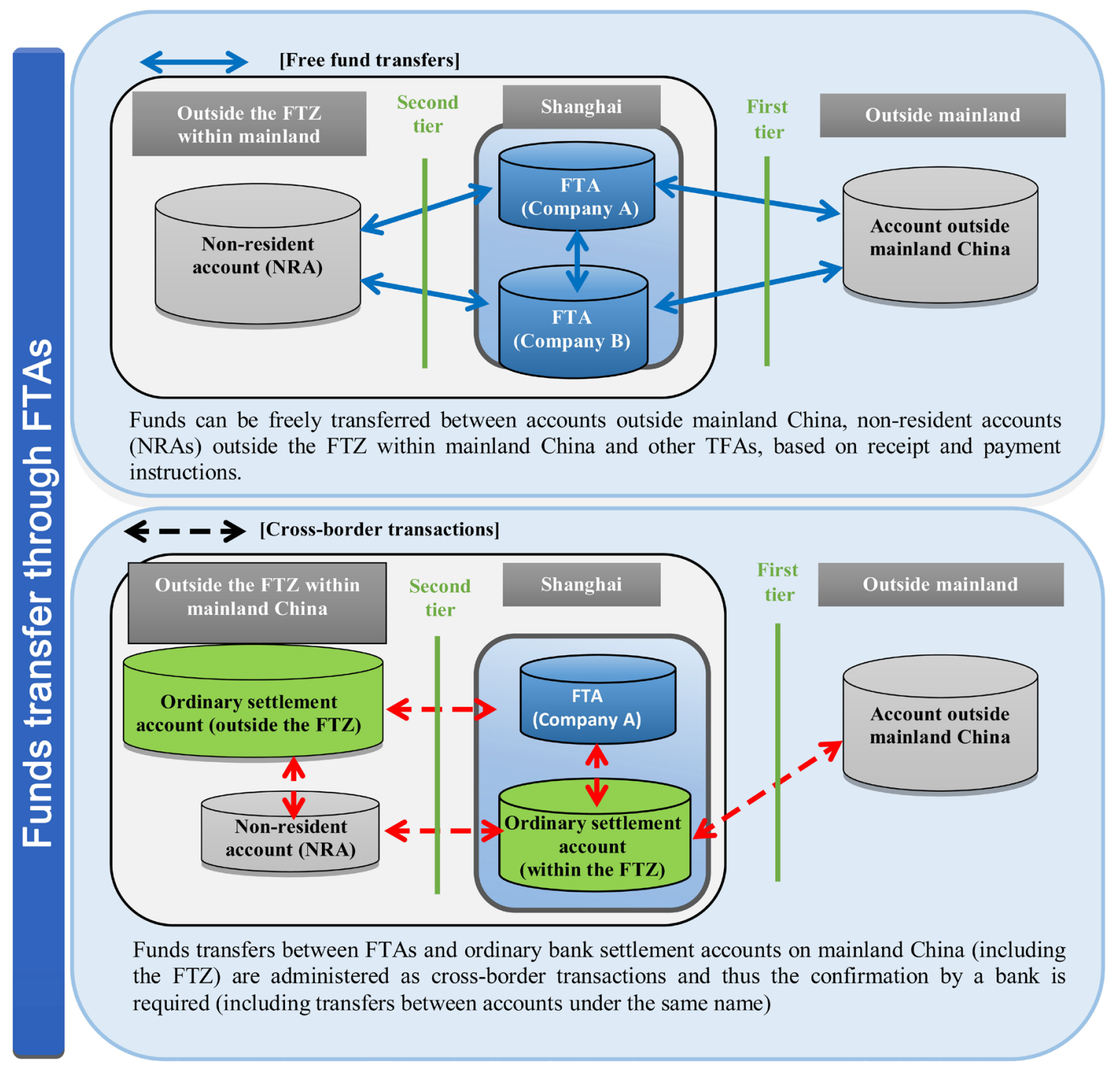

Figure 4. Financial advantages of SHFTZ (Adopted from: Mizuho Bank, 2015) [46]. 


\subsection{Ghana Export Processing Zone Incentives}

Enterprises established in these zone enjoy these incentives: 100\% exemption from payment of direct and indirect duties and levies on all imports for production and exports from free zones, $100 \%$ exemption from payment of income tax on profits for 10 years and shall not exceed 8 percent thereafter, total exemption from payment of withholding taxes from dividends arising out of free zone investments, total exemption from payment of withholding taxes from dividends arising out of free zone investments, relief from double taxation for foreign investors and employees, no import licensing requirements, minimal customs formalities, $100 \%$ ownership of shares by any investor-foreign or national in a free zone enterprise is allowed, there are no conditions or restrictions on: repatriation of dividends or net profit; payments for foreign loan servicing; payments of fees and charges for technology transfer agreements; and remittance of proceeds from sale of any interest in a free zone investment, free zone investors have the permission of operating foreign currency accounts with banks in Ghana, annually in the local market up to $30 \%$ of sale of produced goods and services of the free zone enterprise are allowed, free zone investments are guaranteed against nationalization and expropriation, relief from various bureaucratic restrictions and other statutory requirements, investment approval not exceeding 28 working days, and accelerated on-site customs inspection [27].

\section{Registration and Licensing of Enterprises at the Ghana Free Zones}

The process of registering the obtaining legal license involves: Incorporate a company in Ghana with the Registrar General's Department, obtain and complete Ghana Free Zone Board Application Form (US\$100.00) and submit with Business Plan with Copy of incorporation documentation, evidence of possession/lease of land or intent to acquire such property, MOU with potential clients, Environmental Protection Agency(EPA) permit, evidence of funding and any other relevant document [38].

\section{Comparative Analysis of Free Zone Infrastructure}

\subsection{China (Shanghai) Pilot Free Trade Zone Infrastructure}

The space in the zone is limited; however, originally four (4) bonded zones were recently expanded. Now the zone covers 120 square kilometres and is currently composed of seven existing bonded zones, these are: Waigaoqiao Free Trade Zone and Waigaoqiao Free Trade Logistics Park, Yangshan Free Trade Port Area; the first free trade zone in China, Pudong Airport Comprehensive Free Trade Zone; a deep-water port, key component of Shanghai Port, Lujiazui Finance and Trade Development Zone located west to Shanghai Pudong international Airport, Jinqiao Economic and Technological Development Zone a financial services hub and Zhangjiang High-tech Industrial Development Zone; an advanced manufacturing and manufacturer services area, high-tech manufacturing and medical services specialization area [36]. 


\subsection{Ghana Export Processing Zone Infrastructure}

\subsubsection{Tema Export Processing Zone}

The flagship of the Ghana Free Zones Program, the Tema Export Processing Zone, is located in Tema. Tema, one of the Ghana's industrial and residential towns has the largest seaport in the country. Its location is about 24 kilometres from Ghana's international airport. Tema is also among the fastest growing cities in the country. The Tema Export Processing Zone has a total area of 1,200 acres and affords investors a suitable environment for production such as the convergence of all frontline export promotion institutions into a one-stop-shop. There are good road networks that link Tema EPZ to the airport and seaport [37].

\subsubsection{Ashanti Export Processing Zone.}

The Ashanti EPZ with a land area of 1099 acres is located in the Ashanti Region in Ghana and close to the inland port of Boankra. This enclave when developed is envisaged to be an ICT Park. It is to provide the necessary telecommunications enabling infrastructure for investors. It would have facilities including, warehousing, agro processing and light industrial/electronic sub-enclaves with a complementary residential estate for enclave employees [37].

\subsubsection{Sekondi Export Processing Zone}

This zone has been earmarked for oil refinery and related activities. It has a land area of 2200 acres. A direct rail link to Ghana's second seaport is ideal to harness the proximity of this EPZ for heavy industrial activities [37].

\subsubsection{Shama Export Processing Zone}

A third zone, the Shama Export Processing Zone, has been designated as a multi-purpose enclave and has a land area of 3000 acres. With this enclave interested developers are welcomed to develop the enclave [37].

\section{Free Zone Performance: A comparative Analysis}

\subsection{Shanghai Pilot Free Trade Zone Performance}

Progress in the following areas has been in place since the commencement of the SPFTZ in 2013. First of all, there has been a quick increase in newly registered enterprises. There were 12,547 new registered enterprises in the SPFTZ by 26 September 2014, consisting of 10,788 domestic investment enterprises and 1759 foreign investment enterprises. As seen in Figure 5, there was a steady increase, from $11.6 \%$ to $24.9 \%$ of the proportion of foreign investment enterprises [26]. Secondly, financial innovation in SHFTZ has made progress. As at the period of discussion, there were 484 free trade accounts operated by enterprises, and the RMB balance of these accounts was about 90 million. As can be seen in Figure 6 in the first quarter after the inception of the SHFTZ, not much growth or contribution to the Shanghai economy was observed, only 5.68\%. SHFTZ was estimated to have contributed about $13.2 \%$ of Shanghai GDP, increasing to $15.2 \%$ 
and $22.9 \%$ in 2015 and 2016 respectively. These figures give a clear indication of the contribution of the SHFTZ to the acceleration of the economy of the area as in accordance with the maturity expectations [47].

Many financial institutions have business in the SHFTZ, including 23 foreign banks, 14 Chinese banks, three security companies and 11 insurance companies. Twenty-eight (28) enterprises had built so called "RMB money ponds" in the SHFTZ, having a balance of 16.9 billion. The RMB cross-border settlement in the SHFTZ is 111.5 billion. Seventy (70) of the enterprises are involved with RMB finance from abroad and are running on a balance of 16.06 billion [26].

Registered enterprises within the SHFTZ have continuously increased to a

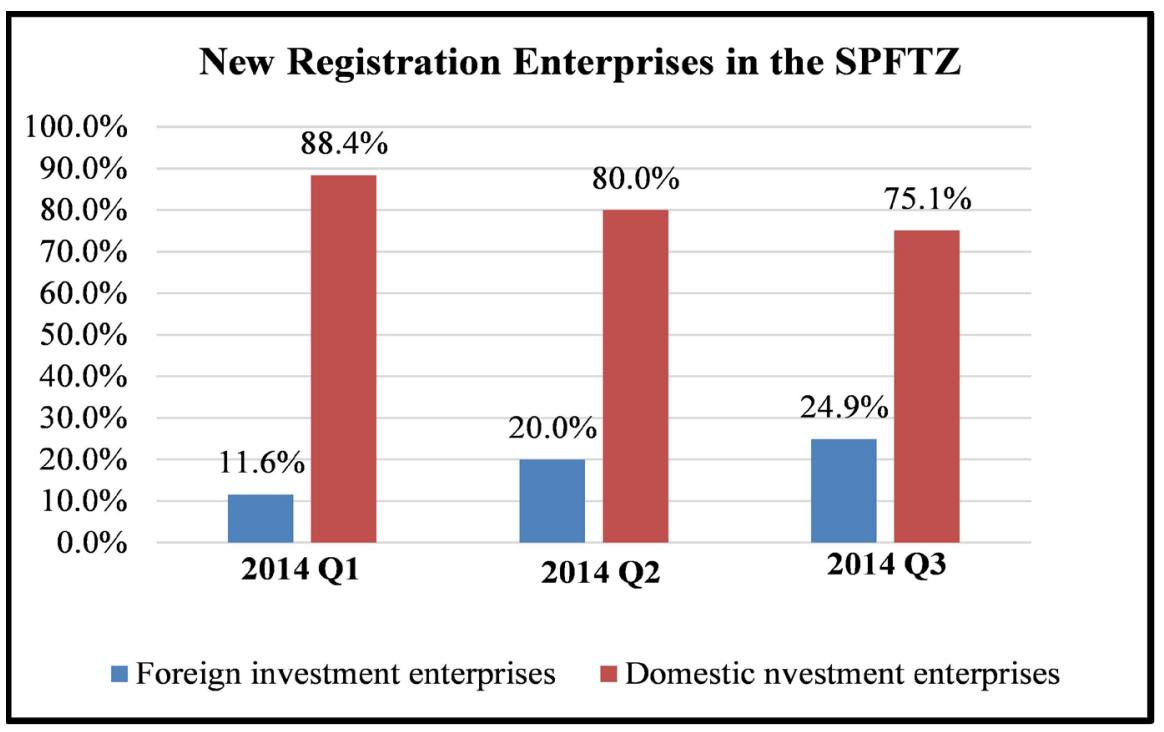

Figure 5. New Registered Enterprises in SPFTZ (Adopted from: Yao and Whalley, 2016) [26].

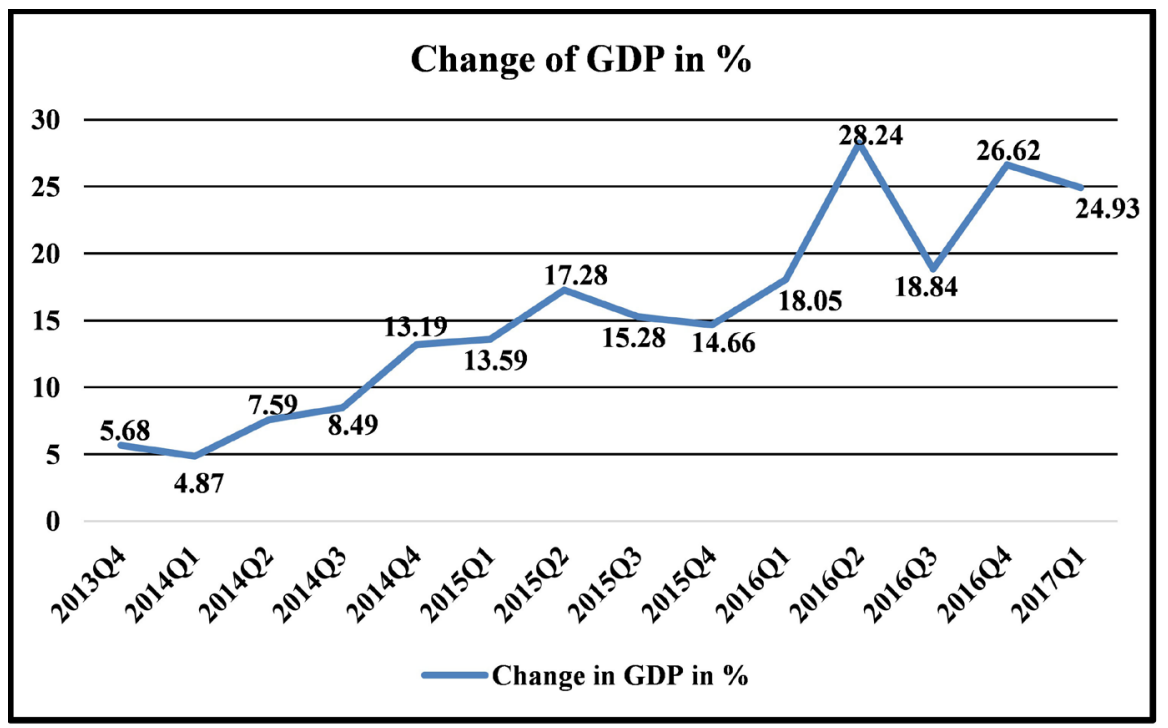

Figure 6. The policy effect of SHFTZ on Shanghai GDP (Adopted from: Huang et al. 2017) [47]. 
total of 25,304 of which sixty-seven percent (67\%) of them were registered after the SHFTZ was set up. Meanwhile, each enterprise's registered capital has increased from 43.71 million to 63.36 million [48]. As informed by the local official of the SHFTZ, in 2015, the number of registered foreign-invested enterprises within the SHFTZ increased by one and a half times that in 2014. This as they noted, covers about half the total number in the whole city of Shanghai. Foreign-invested enterprises in the SHFTZ have increased from 5\% (from the beginning) to $20 \%$ for the period under discussion. The average registered capital of foreign-invested enterprises is twice that of domestic-invested enterprises [48].

Table 1 shows the changes on income, tax, profits, and number of employees before and after the SHFTZ was set up in 2013. Apart from few figures like Investment

Table 1. The Main Economic Index of the SHFTZ (2012 2014) (Adopted from: Hu, 2017) [48].

\begin{tabular}{|c|c|c|c|c|}
\hline Index & Unit & 2012 & 2013 & 2014 \\
\hline Total Income & Billion (Yuan) & 1284.972 & 1442.44 & 1609.455 \\
\hline Income from the Headquaters & Billion (Yuan) & 649.729 & 712.986 & 779.471 \\
\hline Total Profits & Billion (Yuan) & 46.453 & 55.948 & 63.790 \\
\hline Sales in Retail & Billion (Yuan) & 1099.809 & 1237.336 & 1387.941 \\
\hline Maritime Logistics Income & Billion (Yuan) & 84.916 & 103.347 & 120.369 \\
\hline Total Industrial Output Value & Billion (Yuan) & 72.778 & 64.616 & 57.270 \\
\hline Number of Employees & Million & 0.269 & 0.2861 & 0.2961 \\
\hline Investment on Fixed Assets & Billion (Yuan) & 4.84 & 5.103 & 3.042 \\
\hline Total Imports and Exports & Billion (Dollar) & 113.052 & 113.433 & 124.1 \\
\hline Imports & Billion (Dollar) & 86.71 & 83.93 & 90.954 \\
\hline Exports & Billion (Dollar) & 26.342 & 29.503 & 33.146 \\
\hline Tax Income & Billion (Yuan) & 42.896 & 50.827 & 57.639 \\
\hline Customs Office Income & Billion (Yuan) & 98.878 & 93.773 & 98.255 \\
\hline Newly Set-Up Enterprises & Units & 788 & 4416 & 11440 \\
\hline Foreign Investment Projects & Units & 164 & 359 & 2057 \\
\hline The Capital of FDI in Contract & Billion (Dollar) & 1.616 & 1.909 & 11.795 \\
\hline Registered Capital of FDI & Billion (Dollar) & 0.54 & 0.695 & 0.621 \\
\hline Registered Capital from Domestic Enterprises & Billion (Yuan) & 5.626 & 85.362 & 332.887 \\
\hline Container Handling Capacity in Total & Million Containers & 29.513 & 30.585 & 32.366 \\
\hline Waiguoqiao Port & Million Containers & 15.363 & 16.22 & 17.164 \\
\hline Yangshan Port & Million Containers & 14.15 & 14.365 & 15.202 \\
\hline Cargo Handling Capacity of Pudong Airport & Million Tons & 0.295 & 0.2915 & 0.3182 \\
\hline Imports and Exports via Waigaoqiao Port & Billion (Yuan) & & 2251.11 & 2384.89 \\
\hline Imports and Exports via Yangshan Port & Billion (Yuan) & & 1723.53 & 1827.45 \\
\hline Imports and Exports via Pudong Airport & Billion (Yuan) & & 1982.91 & 2137.23 \\
\hline
\end{tabular}


on Fixed Assets and Total Industrial Output Value, most others have indicated an increasing tendency. The Registered Capital from Domestic Enterprises, Foreign Investment Projects, and increase of the Newly Set-up Enterprises Registered Capital of FDI are very impressive merely because of the release market access. Table 2 shows a picture in parallel to the general one of China's imports

Table 2. Top 30 Countries and Areas Which China Has Imports from and Exports to via SHFTZ (Unit: million dollars) (Adopted from: $\mathrm{Hu}, 2017$ ) [48].

\begin{tabular}{|c|c|c|c|c|}
\hline No. & Country/ Area & Imports & Country/Area & Exports \\
\hline 1 & Japan & 10920.64 & Hong Kong & 7132.89 \\
\hline 2 & USA & 10040.49 & USA & 4722.53 \\
\hline 3 & uk & 7679.82 & Japan & 2869.8 \\
\hline 4 & Malaysia & 6697.94 & Singapore & 2843.1 \\
\hline 5 & Germany & 6204.94 & Korea & 2171.16 \\
\hline 6 & Korea & 6078.15 & Malaysia & 1664.78 \\
\hline 7 & Taiwan & 4196.72 & Taiwan & 1483.04 \\
\hline 8 & France & 3762.76 & Germany & 1072.28 \\
\hline 9 & Chile & 2972.67 & The Netherland & 968.23 \\
\hline 10 & Switzerland & 2526.77 & Australia & 950.69 \\
\hline 11 & Singapore & 1997.85 & India & 868.51 \\
\hline 12 & Italy & 1837.16 & Thailand & 591.93 \\
\hline 13 & Viet Nam & 1581.12 & Viet Nam & 573.67 \\
\hline 14 & The Philippines & 1567.96 & Indonesia & 422.16 \\
\hline 15 & Australia & 1509.61 & Mexico & 344.31 \\
\hline 16 & Russia & 1456.66 & UK & 340.69 \\
\hline 17 & India & 1430.2 & The Philippines & 338.1 \\
\hline 18 & Thailand & 1385.87 & Belgium & 267.98 \\
\hline 19 & Costa Rica & 1141.44 & France & 267.5 \\
\hline 20 & Ireland & 942.97 & Brazil & 246.3 \\
\hline 21 & The Netherland & 807.34 & Spain & 194.07 \\
\hline 22 & Mexico & 671.18 & Iran & 188.48 \\
\hline 23 & Belgium & 668.12 & UAE & 182.99 \\
\hline 24 & Sweden & 636.75 & Russia & 172.2 \\
\hline 25 & Zambia & 610.91 & Italy & 161.65 \\
\hline 26 & Brazil & 564.31 & Canada & 116.98 \\
\hline 27 & Peru & 545.64 & Turkey & 112.54 \\
\hline 28 & Indonesia & 503.81 & Pakistan & 98.22 \\
\hline 29 & Spain & 487.91 & Bangladesh & 97.72 \\
\hline 30 & Austria & 479.06 & Slovakia & 93.11 \\
\hline
\end{tabular}


and exports due to the fast increase rate of imports and exports within the SHFTZ. What is significant here is the volume of imports and exports via the SHFTZ, particularly with regards to the rapid increase after the SHFTZ was set up. This proves the SHFTZ concept's attraction to investors [48].

\subsection{Ghana Export Processing Zone Performance}

\subsubsection{Registration of Companies}

Since the inception of the free zones program, a number of companies have been licensed under the scheme in order to benefit from the incentives that render them competitive and also give them the opportunity to reach a large international market. The Ghana Free Zones Board has progressively registered new companies each year. Total number of registered free zone companies as at 2014 was 352; the yearly distribution from 1996/97 to 2014 is shown in the graph (Figure 7).

\subsubsection{Employment Generation}

Total employment generated under the Free Zone Program as at the end of 2014 was 30,271 the yearly distribution is shown in Figure 8.

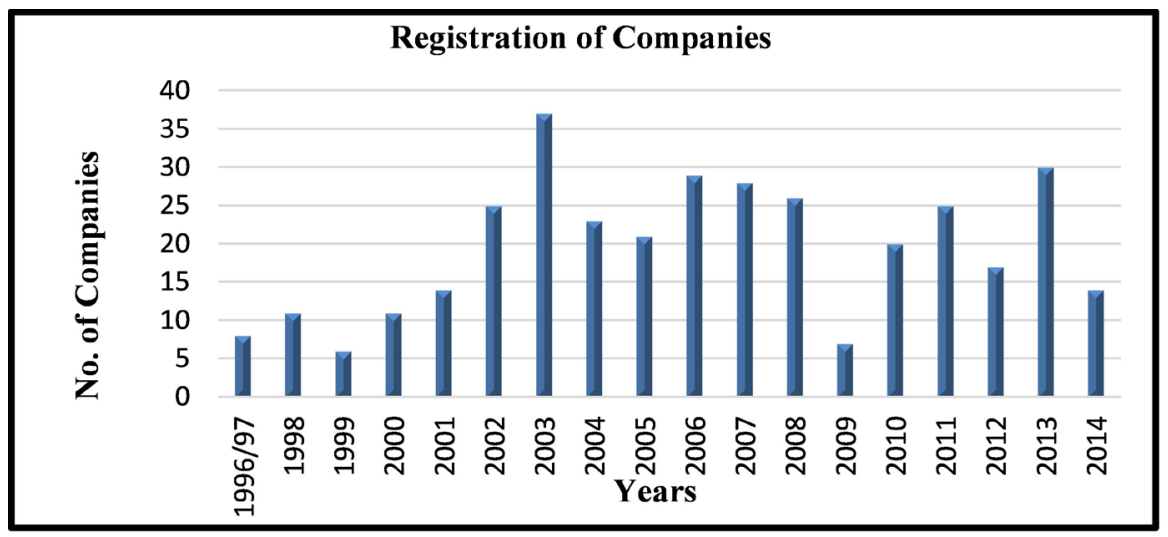

Figure 7. Registration of Companies in Ghana free zone (Deduced form: GFZB Annual Report, 2014) [49].

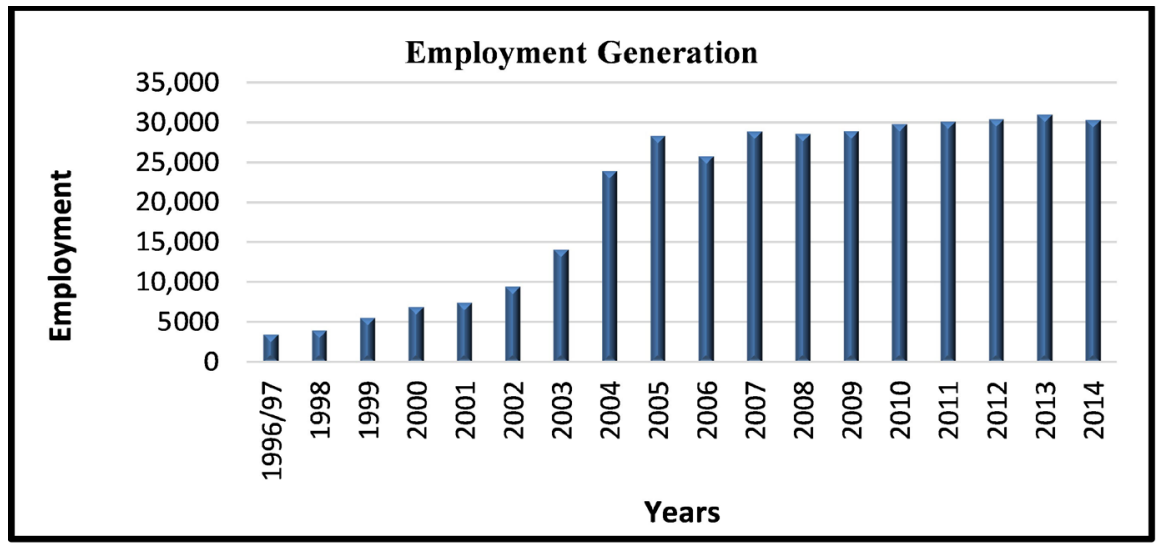

Figure 8. Employment Generation at the Ghana free zone (Deduced form: GFZB Annual Report, 2014) [49]. 


\subsubsection{Production Value}

Annual production value of Free Zones Companies in 2014 was US\$2200.18 M. The yearly figures from 1996/97 to 2014 are shown in the graph (Figure 9).

\subsubsection{Total Expor}

Annual total export value of licensed Free Zone Enterprises from 1998 to 2014 amounted to US\$26,563.33. The breakdown is shown in Figure 10.

\subsubsection{Capital Invested}

During the year under review US $\$ 167.47 \mathrm{M}$ was invested in various sectors of the free zone program. The cumulative amount of capital invested in free zones since the inception of the program in 1996/97 to the end of 2014 stands at US $\$ 2684.90 \mathrm{M}$. The breakdown of investments over the years is shown in Figure 11. Figure 12 shows the contribution of Ghana EPZ to National Gross Export for the period 2004 to 2014 .

\section{Variation in the Zone Performance}

\subsection{Variation in the Zone Performance: The Shanghai Pilot Free Trade Zone Performance}

Considering the above discussions, the SHFTZ was constituted as a form of pilot

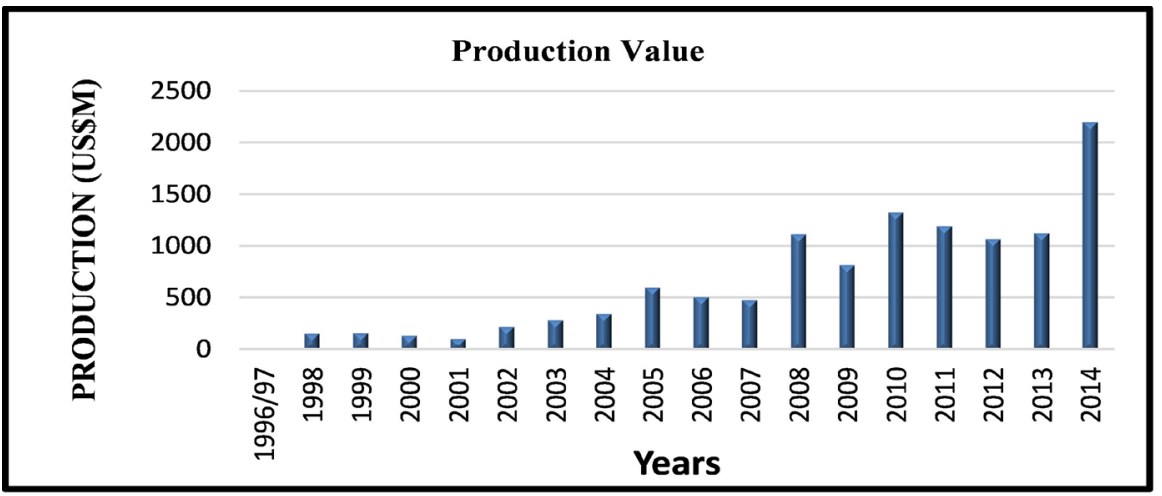

Figure 9. Production Value at Ghana free zone (Deduced form: GFZB Annual Report, 2014) [49].

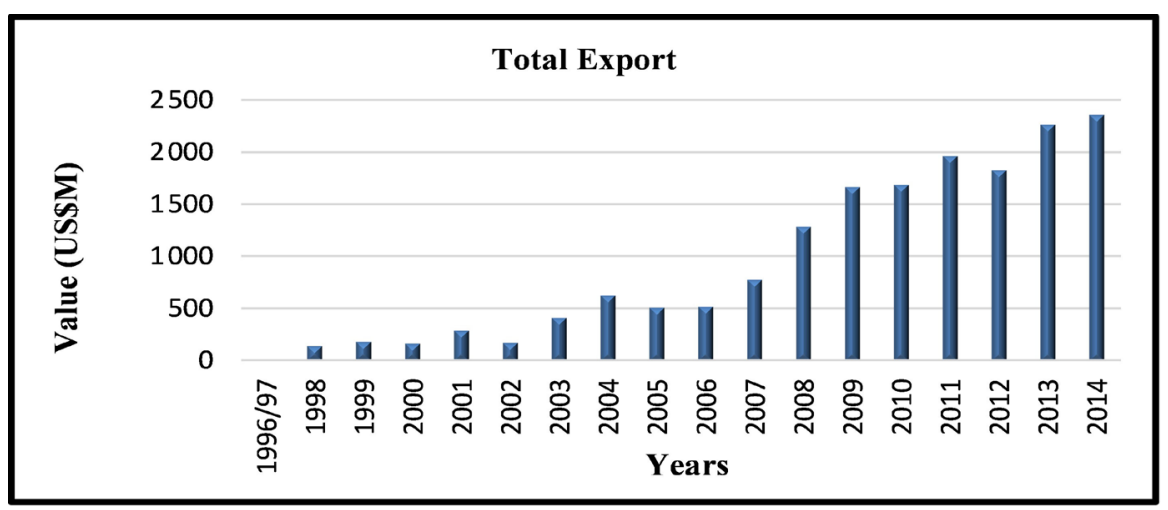

Figure 10. Total Export from Ghana free zone (Deduced form: GFZB Annual Report, 2014) [49]. 


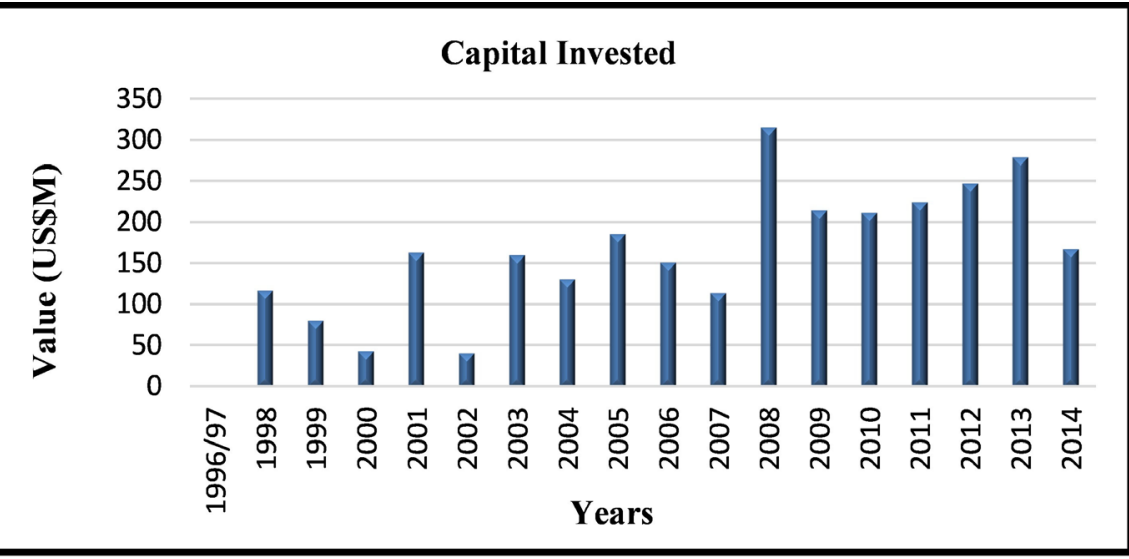

Figure 11. Capital invested by Enterprises at Ghana free zone (Deduced form: $G F Z B$ Annual Report, 2014) [49].

program to increase investment from foreign investors. The benefits of foreign investment are relatively obvious-more capital, increased access to foreign markets, economic development, and availability of foreign products to domestic consumers notwithstanding, there are concerns to foreign investment. Firstly, there is a probability of it influencing domestic politics. China has historically resisted foreign influence strongly, so this SHFTZ has been a significant policy consideration. Secondly, there was a reduction in fund received by the central government due to the incentives introduced by the program. Shanghai, the financial centre of China was chosen strategically as the testing grounds for the economic reforms. This was to enable the program to balance the negative and positive sides of foreign investment promotion, to limit the risk that SHFTZ can bring while maximizing the potential gains. Shanghai hold offices for a number of foreign companies and is also noted for hosting conferences and events on trade promotion. So initially consolidation of the existing four Free Trade Zones was a good way of making use of existing infrastructure and also taking advantage of proximity to foreign companies. With a GDP contribution of $5.68 \%$, $13.2 \%, 15.2 \%$ and $22.9 \%$ from the first quarter after the inception of the FTZ, at the end of 2014, 2015 and 2016 respectively, to the Shanghai economy it can be said finally that the SHFTZ idea has yielded its intended goals significantly.

\subsection{Variation in the Zone Performance: The Ghana Free Zones}

There has been year on year increase in the number of companies registering for the free zone initiative. Even though the rate of export has increased over the years under discussion, it has not been that prominent. Taking the exports from the export processing zone as a proportion of the gross exports of Ghana, one can see an average of $15 \%$ to the gross exports of the country as can be seen in Figure 12. This is not good enough. Ghana would need to fully develop all the areas earmarked for development into Export Processing Zones. Lessons of the decentralized structure being used by China can be learnt to help grow this initiative. The setting up of the three Development Authorities by current government 


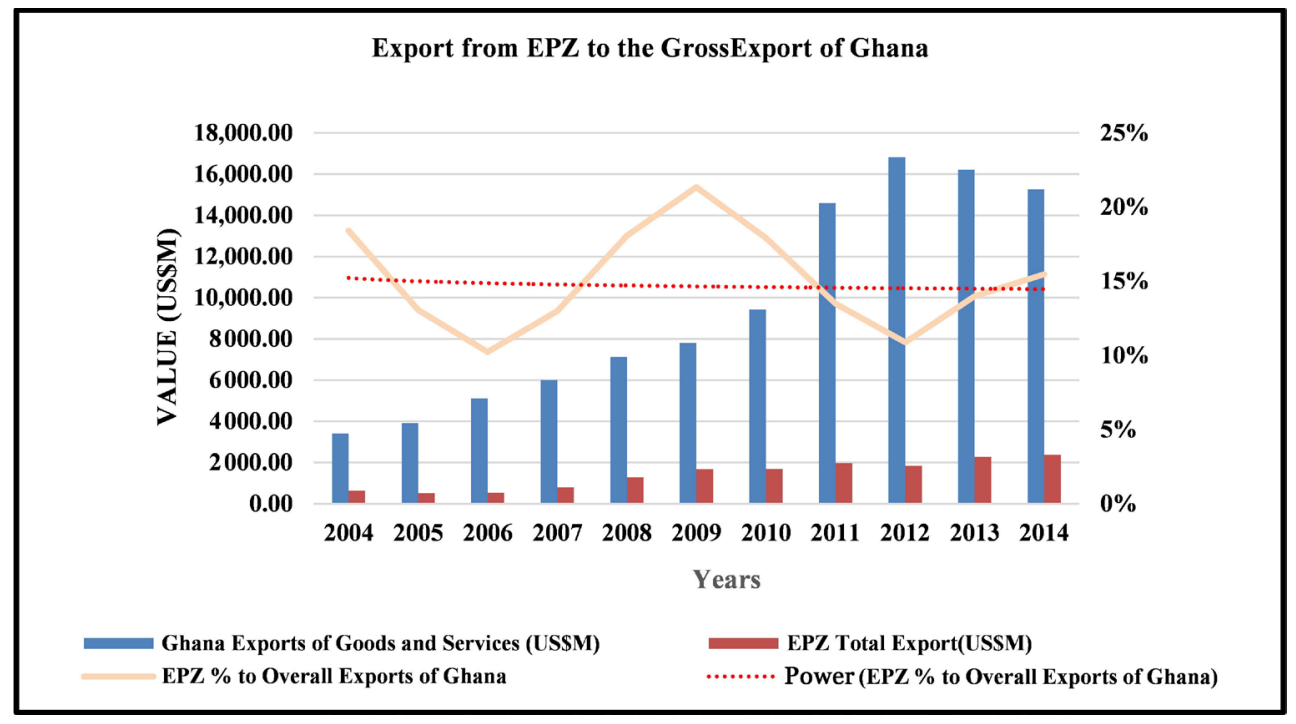

Figure 12. The contribution of Ghana EPZ to National Gross Export (Deduced form: [49] [50] $[51])$.

can to a greater extent tow the China line of decentralized zone creation and governance. While business registration approval duration for SHFTZ has been reduced to less than a week, while import and export license takes 2 weeks, the approval duration for the Ghana free Zones take about 28 days.

\section{Conclusion}

A comparative analysis of effective Free Trade Zone Policies in Ghana using China (Shanghai) Pilot Free Trade Zone ("SHFTZ") as a model has been done. The pilot project of the Shanghai free trade zone was successful in its implementation, leading to increase in zone demographic area the elimination of some trade regulations in China. The decentralized nature of the governance structure of the Shanghai free trade zone and the quality of infrastructure have been major success factors. The Ghana export processing zone on the other hand has been performing fairly well, but can do better. There has been a gradual increase in the firms registering and carrying out business in the zone. The Export processing zone was initiated with an important aim of boosting the gross national export but has not been contributing much since its inception.

\section{Recommendation}

- There should be the necessary regulatory amendment to streamline company registration with a one-stop-shop approach.

- The processes of relevant institutions like the Customs, Excise \& Preventive Service, the Ghana revenue Authority, the registrar General department etc. need the necessary regulatory amendment to streamline their processes, red tape and bureaucracy to aid the agencies fast track commercial activities for these companies.

- There should be massive development of railways and other relevant infra- 
structure.

- The Act of Parliament that set out the regulations for the Free zones provides Private development of these zones and should be focal point of government to encourage this to increase the viability of success and zones operations.

- The Development Authorities being set up by the current government, when fully functional should work towards the development of more Zones and the amendment of the relevant laws.

- Finally, instead of inventing the wheel, why not just use the already invented wheel. Ghana should learn from China.

\section{Author's Contributions}

Jonathan Banahene and Vu Thi Van collected and analyzed the data; Ebenezer Nickson Neequaye and Huang Dechun wrote the paper; Stella Fynn provided extensive feedback and comments on the article and edited the paper.

\section{Conflicts of Interest}

The authors declare no conflict of interest.

\section{References}

[1] Wahyuni, S. and Esther Sri Astuti, S.A. (2011) Competitiveness of Free Trade Zone Area: Comparison between Indonesia \& ASEAN Countries. Graduate School of Management Research Paper No. 13-03, Society of Interdisciplinary Business Research (SIBR) 2011 Conference on Interdisciplinary Business Research, Universitas Indonesia.

[2] Kathiann, M.K. (2008) Open for Debate: Free Trade 23.

[3] Tiefenbrun, S. (2013) U.S. Foreign Trade Zones of the United States, Free-Trade Zones of the World, and Their Impact on the Economy. Journal of International Business and Law, 12, 149.

[4] Farole, T. and Akinci, G. 2011) World Bank, Special Economic Zones: Progress, Emerging Challenges, and Future Directions 3.

http://documents.worldbank.org/curated/en/752011468203980987/pdf/638440PUB 0Exto00Box0361527B0PUBLIC0.pdf

[5] Diamond, H.W. (1980) Tax-Free Trade Zones Aid Both Exporters and Importers. The American Banker.

[6] Diamond, W.H. and Diamond, D.B. (1995) Tax-Free Trade Zones of the World. Unz \& Company, Middlesex.

[7] UNDP (2015) If Africa Builds Nests, Will the Birds Come? Comparative Study on Special Economic Zones in Africa and China. Working Paper series, NO. 06.2015. http://www.cn.undp.org/content/china/en/home/library/south-south-cooperation/i f-africa-builds-nests--will-the-birds-come-.html

[8] Creskoff, S. and Walkenhorst, P. (2009) Implications of WTO Disciplines for Special Economic Zones in Developing Countries.

[9] Engman, M., Onodera, O. and Pinali, E. (2007) Export Processing Zones: Past and Future Role in Trade and Development (No. 53). OECD Publishing.

[10] Wong, S.-W. and Tang, B.-S. (2005) Challenges to the Sustainability of "Develop- 
ment Zones": A Case Study of Guangzhou Development District, China. Cities, 4, 303-316.

[11] ACTRAV Bureau for Workers' Activities (2014) Trade Union Manual on Export Processing Zones. International Labour Organization. https://www.ilo.org/actrav/info/pubs/WCMS_324632/lang--en/index.htm

[12] Madani, D. (1999) A Review of the Role and Impact of Export Processing Zones. Vol. 2238, World Bank Publications. https://doi.org/10.1596/1813-9450-2238

[13] Cling, J.P. and Letilly, G. (2001) Export Processing Zones: A Threatened Instrument for Global Economy Insertion. DIAL, Documento de Trabajo, DT/2001/17.

[14] Zeng, D.Z. (2010) Building Engines for Growth and Competitiveness in China: Experience with Special Economic Zones and Industrial Clusters. World Bank Publications. https://doi.org/10.1596/978-0-8213-8432-9

[15] Schrank, A. (2001) Export Processing Zones: Free Market Islands or Bridges to Structural Transformation? Development Policy Review, 19, 223-242. https://doi.org/10.1111/1467-7679.00132

[16] Litwack, J.M. and Qian, Y. (1998) Balanced or Unbalanced Development: Special Economic Zones as Catalysts for Transition. Journal of Comparative Economics, 26, 117-141. https://doi.org/10.1006/jcec.1997.1502

[17] Basile, A. and Germidis, D. (1984) Investing in Free export Processing Zones. Development Centre of the Organisation for Economic Co-operation and Development.

[18] Zeng, D.Z. (2016) Special Economic Zones: Lessons from the Global Experience, PEDL Synthesis Paper Series.

[19] Jalil, A. and Mahmud, S.F. (2009) Environment Kuznets Curve for $\mathrm{CO}_{2}$ Emissions: A Cointegration Analysis for China. Energy Policy, 37, 5167-5172. https://doi.org/10.1016/j.enpol.2009.07.044

[20] Coondoo, D. and Dinda, S. (2002) Causality between Income and Emission: A Country Group-Specific Econometric Analysis. Ecological Economics, 40, 351-367. https://doi.org/10.1016/S0921-8009(01)00280-4

[21] Stern, D.I. (2004) The Rise and Fall of the Environmental Kuznets Curve. World Development, 32, 1419-1439. https://doi.org/10.1016/j.worlddev.2004.03.004

[22] Aslanidis, N. and Iranzo, S. (2009) Environment and Development: Is There a Kuznets Curve for $\mathrm{CO}_{2}$ Emissions? Applied Economics, 41, 803-810. https://doi.org/10.1080/00036840601018994

[23] Perman, R. and Stern, D.I. (1999) The Environmental Kuznets Curve: Implications of Non-Stationarity.

[24] Schoenbaum, T.J. (1992) Free International Trade and Protection of the Environment: Irreconcilable Conflict? American Journal of International Law, 86, 700-727. https://doi.org/10.2307/2203788

[25] Shah, K.U. and Rivera, J.E. (2007) Export Processing Zones and Corporate Environmental Performance in Emerging Economies: The Case of the Oil, Gas, and Chemical Sectors of Trinidad and Tobago. Policy Sciences, 40, 265-285. https://doi.org/10.1007/s11077-007-9045-8

[26] Yao, D. and Whalley, J. (2016) The China (Shanghai) Pilot Free Trade Zone: Background, Developments and Preliminary Assessment of Initial Impacts. The World Economy, 39, 2-15. https://doi.org/10.1111/twec.12364

[27] Ghana Free Zones Authority (1995) The Free Zone Act. http://www.gfzb.gov.gh/pdf/Free\%20Zones\%20Act.pdf 
[28] Warr, P.G. (1987) Export Promotion via Industrial Enclaves: The Philippines' Bataan Export Processing Zone. The Journal of Development Studies, 23, 220-241. https://doi.org/10.1080/00220388708422028

[29] Kossof, P. (2014) China's Pilot Free Trade Zone: Shanghai Free Trade Zone and the Potential Future of Free Trade Zones in Mainland China. International Journal of Law and Legal Jurisprudence Studies.

[30] Sit, V.F. (1985) The Special Economic Zones of China: A New Type of Export Processing Zone? The Developing Economies, 23, 69-87. https://doi.org/10.1111/j.1746-1049.1985.tb01092.x

[31] (1979) The Law of the People's Republic of China on Joint Ventures Using Chinese and Foreign Investment.

[32] Zhong, G. (1984) The Sixth Five-Year Plan of the People's Republic of China for Economic and Social Development: 1981-1985. Foreign Languages Press, Beijing.

[33] Meng, G. (2003) The Theory and Practice of Free Economic Zones: A Case Study of Tianjin, People's Republic of China. Doctoral Dissertation.

[34] Trade Policy Review China, Report by the Secretariat, WT/TPR.S/199.

[35] Shen, W. and Vanhullebusch, M. (2015) Where Is the Alchemy? The Experiment of the Shanghai Free Trade Zone in Freeing the Foreign Investment Regime in China. European Business Organization Law Review, 16, 321-352. https://doi.org/10.1007/s40804-015-0008-9

[36] Radelet, S. (1999) Manufactured Exports, Export Platforms, and Economic Growth. Harvard Institute for International Development Consulting Assistance on Economic Reform II, Cambridge, 43.

[37] Angko, W. (2014) Analysis of the Performance of Export Processing Zones in Ghana. Journal of Business Administration and Education, 5.

[38] Darko-Opoku, A.O. (1995) Ghana Free Zones Programme: Providing a Conducive Investment Environment. Country Presentation in Italy. http://sedi2.esteri.it/sitiweb/SistemaPaese/Ghana_Free_Zones_Board.pdf

[39] Deyo, F.C. (1987) Coalitions, Institutions, and Linkage Sequencing-Toward a Strategic Capacity Model of East Asian Development. In: Deyo, F.C., Ed., The Political Economy of the New Asian Industrialism, Cornell University Press, Ithaca, 227-247.

[40] Shanghai Free Trade Zone. http://en.shftz.gov.cn/government-affairs/organization/

[41] GFZA Profile (2018) Ghana Free Zones Authority. http://gfzb.gov.gh/en/index.php/gfza-profile/

[42] Grmanova, B. CzehTrade. Shanghai Free Trade Zone. https://www.mzv.cz/file/2508780/ShanghaiFreeTradeZone.pdf

[43] KPMG (2014) Pilot Free Trade Zone Series-Regulation for China (Shanghai) Pilot Free Trade Zone Has Been Released.

https://www.kpmg.com/CN/en/IssuesAndInsights/ArticlesPublications/Newsletters /ChinaAlerts/Documents/China-tax-alert-1408-22-Regulation-for-China-ShanghaiPilot-Free-Trade-Zone-released.pdf

[44] Maarten, R. (2015) China: Shanghai Free Trade Zone Update: Real Benefits to Foreign Investors.

http://www.mondaq.com/x/430776/international+trade+investment/Shanghai+Free + Trade+Zone+Update+Real+benefits+to+foreign+investors

[45] EU SME Centre Webinar (2014) Using Free Trade Zones When Importing to 
China. https://www.youtube.com/watch?v=7T_bXvAGDNg

[46] Mizuho Bank (2015) Free Trade Accounts (FTAs).

http://www.mizuhobank.com/service/global/cndb/rmb/pdf/fta.pdf

[47] Huang, D., Van, V.T., Hossain, M.E. and He, Z. (2017) Shanghai Pilot Free Trade Zone and Its Effect on Economic Growth: A Counter-Factual Approach. Open Journal of Social Sciences, 5, 73. https://doi.org/10.4236/jss.2017.59006

[48] Hu, J. (2017) A Retrospective View on the First Three Years of China (Shanghai) Pilot Free Trade Zone. The Chinese Economy, 50, 225-237. https://doi.org/10.1080/10971475.2017.1321458

[49] GFZB (2014) Ghana Free Zones Board Annual Report \& Audited Accounts 2014. http://gfzb.gov.gh/en/index.php/annual-report/

[50] BOG (2014) Bank of Ghana Annual Report 2014. http://www.bog.gov.gh

[51] BOG (2009) Bank of Ghana Annual Report 2009. http://www.bog.gov.gh 